\section{B A Institute of \\ YK Business Administration \\ 六下 \\ Karachi \\ Leadership and Ideas for Tomorrow}

\section{Business Review}

Volume 12 Issue 2 July - December 2017

7-1-2017

\title{
Ownership structure changes, reforms and corporate restructuring: Evidence from Japan
}

\author{
Muhammad Shahid Iqbal \\ Department of Economics, University of Karachi, Pakistan \\ Khalid Mustafa \\ Department of Economics, University of Karachi, Pakistan
}

Follow this and additional works at: https://ir.iba.edu.pk/businessreview

\section{c) (i)}

This work is licensed under a Creative Commons Attribution 4.0 International License.

\section{Recommended Citation}

Iqbal, M. S., \& Mustafa, K. (2017). Ownership structure changes, reforms and corporate restructuring: Evidence from Japan. Business Review, 12(2), 33-64. Retrieved from https://doi.org/10.54784/ 1990-6587.1042 


\title{
Ownership structure changes, reforms and corporate restructuring: Evidence from Japan
}

\author{
Muhammad Shahid Iqbal • Khalid \\ Mustafa
}

\begin{abstract}
This study explores the implications of control transfer and ownership structure on firm value and restructuring activities in Japan. We find that conventional banks and business group affiliations negatively impact firm value and organizational restructuring, but foreign and private individual shareholding have a positive impact on firm performance and its ability to restructure internally. Furthermore, the transfer of ownership control to market-oriented investors consistently results in greater firm value and restructuring activities that enhance economic efficiency of listed companies in Japan.
\end{abstract}

Keywords Corporate governance - Organizational restructuring - Keiretsu . Business groups · Japan .

\section{Introduction}

Corporate governance is a multi-dimensional phenomenon that explains the objectivity of the corporate world. It is considered as a framework that can control and monitor firm management to achieve efficient business operations and organizational restructuring. This supports the agency view of financial theory regarding conflict of interest between principal and agents as a governance mechanism. The stakeholder view, on the other hand holds that the corporation is a coalition of stakeholders, by which internal and external stakeholders, like shareholders, managers, financial institutions, non-financial institutions and foreign investors achieve their various interests. Such a corporate governance structure is very complex due to conflicting objectives of stakeholders.

There are two established corporate governance regimes that are practiced

Muhammad Shahid Iqbal

Department of Economics, University of Karachi, Pakistan

E-mail: shahid90aerc20@gmail.com

Khalid Mustafa

Department of Economics, University of Karachi, Pakistan 
in the business world: the Anglo-American system and the bank-based corporate governance system. The Anglo-American governance system is based on the principles of competitive equity markets and shareholder wealth maximization. The bank-based corporate governance system is practiced in Germany, Japan, and South Korea where companies depend heavily on bank financing and are well connected with business group affiliations to maximize the value for all stakeholders.

Jensen (1986) argues that third party control improves resource allocation and financial efficiency in poorly performing firms under the market-oriented corporate governance system. Historically, main banks and business affiliated groups (Keiretsu) have played a dominating role in Japanese listed companies because of their majority shareholdings and long-term business ties. Generally, such investors are known as stable investors and they try to establish long term business ties with firms rather than focus exclusively on the achievement of short-term objectives. These shareholders prefer commercial trade ties and cross-holdings facilitate them to strengthen their corporate aims and relationship with client firms Prowse (1992) Inoue (1999). Furthermore, these shareholdings protect listed companies from financial distress, threats of takeover as well as exposure to external capital markets. In return, stable investors exploit all possible opportunities to accomplish long term growth objectives.

Market-based investors, on the other hand have short-term objectives such as returns maximization, capital gain and rise in cash flows from the business. In the Japanese financial system, the presence of such market based shareholders has gradually increased in the form of equity investment by private domestic investors, inside investors (management and employees) and foreign corporations. According to the empirical findings of Okabe (2004) foreign institutional investors and domestic private shareholders have special financial incentive to monitor the management and emphasize corporate profitability.

The regulatory framework and enactment of new corporate laws have ensured the protection of minority shareholders in pursuit of the market-oriented corporate governance system. Hence, the growing importance of market-oriented investors has converged the corporate governance system in favor of foreign and domestic private shareholders. The clash of interest among various ownership entities has increased spin-overs and corporate restructurings. The corporate control market is hence, under great pressure because of consistent changes in the regulatory framework, diversified investment strategies and policies implemented by corporate management.

Traditionally, the corporate governance system is based on maximization of group interest and is dominated by inter-corporate groupings and business alliances. The corporate reforms in 2006, particularly the three arrow policies under Abenomics in 2013, have drastically changed the direction of the enterprise system due to significant change in the equity and corporate control market. Resultantly, these corporate reforms have directed the attention of the regulator to ensure the following objectives: (i) participation of independent outside directors in the corporate decision making process, (ii) diverting attention from stakeholder value maximization towards shareholder wealth maximization, (iii) augmenting competition in capital and control markets (i.e., takeovers and 
M\&As), (iv) safeguard the rights of minority shareholders and (v) transparency and information disclosure in accounting, financial, and other reporting to investors.

These corporate reforms in the objectivity of ownership are well described in the recent empirical evidence from the Japanese financial and corporate control market. The rapid change in fiscal and employment policies and renewal of incentive schemes by corporate management have resulted in the emergence of new stakeholders and various ownership identities. A persistent decline in shareholding by stable investors has weakened ultimate control and corporate control of market-based investors is gradually rising.

Inoue (1999) has suggested that the relationship between institutional investors and listed companies has become more transactional as compared to long term relationships in the past three decades. The development of the equity and bond market together with financial liberalization has reduced the dependence of listed companies on main bank financing and cross and block holdings Prowse (1992). During the transition period, the internal management of Japanese firms had been continuously engaged in the pursuit of their own vested interests on behalf of shareholders' value maximization objectives. Agency problems and conflict of interest among various stakeholders have significantly enhanced the economic inefficiencies in Japanese stock markets. The formal acknowledgment of shareholder value maximization as the key objective of listed firms instead of wealth maximization of all stakeholders has increased the importance of the corporate control market. New company laws, financial and legal frameworks are now being put in place to divert the focus of the management towards the protection of shareholder rights.

It is expected that the introduction of transparency and disclosure of information laws and involvement of independent directors in the firm's internal decision-making process will reduce the agency cost and economic inefficiency in Japanese corporations. A steady decline in the dominance of stable shareholders has increased the level of competition in the corporate control market and market-oriented investors are significantly replacing their position in the equity market especially since the early 1990s.

The dissolution of cross-holdings and decay in the dominance of the banking system has played a decisive role in the improvement of firm performance and restructuring activities. The equity market pressure and the competition in the corporate control market has enhanced the restructuring of business organization and change in ownership structure has contributed to improvise resource allocation and efficiency of firms. These characteristics and features of the corporate control market suggest that ownership composition and corporate governance have been progressing in the Japanese corporate market. In this study, our main aim is to evaluate the empirical reasoning behind the recent corporate makeup and the corporate governance mechanisms in the Japanese stock markets.

To pursue these objectives, we focus on two perspectives of the corporate system. One is firm performance and the other is the connection between firm performance and restructuring activities. So, we define the following three research questions: 
(1) To what extent does the ownership structure have an influence on firm performance and managerial control?

(2) How does change in corporate control influence firm value and restructuring activities?

(3) Are the ownership identities responsible for poor performance leading firms towards business organizational restructuring?

In this perspective, we try to empirically determine the ramifications of control transfers and ownership structure, stimulated by the modifications in the monetary system, liberalization, and the regulatory policies during the $1990 \mathrm{~s}$ and early 2000s. A univariate and multivariate analysis has been performed to test the hypothesis of the sensitivities of ownership structure and corporate control on firm value and organizational restructuring and to gauge the influence of ultimate ownership on the performance of listed companies in the Japanese stock market. Hence, a detailed comparative analysis of various ownership identities like financial, non-financial and private individual investors is carried out to gauge their relative influence on firm value and restructuring activities.

This paper focuses on corporate governance and aims to (1) examine the effects of ownership structure and regulatory changes in governance structure on firm performance and organizational restructuring in Japan, (2) discover the effects of corporate reforms in governance structure on the relationship between firm performance and restructuring, (3) to explain how the reforms and regulatory changes have influenced firm performance and the process of restructuring in Japanese stock markets.

The main contribution of the research study lies in insights delivered by including a set of untouched variables assessing firms' efficiency and tendency towards restructuring activities. This study will also provide policy guidelines for other countries where the change in ownership and control transfer to various corporate entities has occurred and companies are involved in transactional commercial links within group business ties. This paper is important because it includes the restructuring activities and corporate control transfer to various ownership entities to assess the behaviour of investors during the reforms process in Japan.

In the following section, a detailed review of literature on corporate reforms and firm's behavior towards restructuring has been presented with respect to the Japanese corporate governance system. Section three and four deal with the econometric model and identify the methodological issues related to estimation methods used to carry out the multivariate analysis. The univariate and multivariate estimation results are presented in the fifth section. Lastly, section six presents the summary and concluding remarks.

\section{Literature review}

A study of the history of Japanese corporate ownership is important. It reveals that up to two-thirds of listed Japanese firms' shares are held by other firms Hodder and Tschoegl (1993). Some corporate block holders, called stable shareholders, almost never sell out and consistently support the management. 
A group of companies linked by stable intercorporate shareholdings is called a keiretsu. A keiretsu in which a bank plays a central role is called a bank group or financial keiretsu.

The wave of divestiture and corporate restructuring spread globally during the 1990s Ahmadjian and Robbins (2005a). Japan and many emerging Asian countries, such as China, Thailand, and Hong Kong have ended the 20th century with unadorned economic and social debates on reforms agenda and corporate restructuring Andrews and Chompusri (2001). According to Filatotchev et al (2000) and Makhija and Patton (2004), corporations of transition economies have also pursued corporate restructuring due to poor performance especially in Russia, Ukraine, Belarus, and Czech Republic. A wave of significant restructuring activities has started even in large economies like the U.S and E.U; layoffs and divestitures of businesses are visibly mentioned in corporate governance literature since the 1990s Bühner et al (1997) Cascio and Wynn (2004).

Corporate reforms under Abenomics have prompted many ways of restructuring activities including antitrust policy Harris et al (2004) Lazonick and O'sullivan (2000) Bethel and Liebeskind (1993) and taxation Hoskisson and Hitt (1990) and integration process based on the Western corporate governance style. For instance, both forms of keiretsu, horizontal and vertical act as a governance mechanism in different sectors of the economy in Japan and its effect on firm's restructuring has not been discovered completely Kim et al (2004).

Recently, foreign institutional and domestic private investors are attaining prominence in equity markets due to increasing proportion of their ownership ratio in Japanese stock markets David et al (2006), but studies probing their effects on corporate restructuring are yet very limited Ahmadjian and Robbins (2005b), Ahmadjian and Song (2004). Corporate restructuring activities do not occur frequently in emerging economies where firms are directly managed by family managers who hold significant proportion of company shares La Porta and Lopez-de Silanes (1999).

\subsection{Corporate governance and restructuring}

The most prominent foundation of diversified corporate restructuring is based on the principal-agent model. Various governance factors that influence the transformation of firms are explained by the agency theory Shleifer and Vishny (1991). For instance Hoskisson et al (1994) confirmed the role of ownership structure elements while Berglöf and Perotti (1994), Jensen (1986) and Murphy et al (1991) realistically anticipated that the fear of buy out and takeover prepares the ground for corporate structuring in the U.S. firms.

However Kim et al (2004) claimed that business networking relationship reduces the possibility of organizational change in listed companies in Japan. The above-mentioned studies argue that various elements of corporate reforms either facilitate or hinder restructuring activities. In sum, regulatory bodies have initiated the process of organizational change in Japanese listed companies by directly mandating the keiretsu to improve capital efficiency or through internal and external control on management. 
S. Iqbal, K. Mustafa

In this research paper, we focus on three vital governance factors which have been consistently ignored in corporate research but are recently gaining much attention in Japan. These are foreign ownership Ahmadjian and Song (2004), business group affiliation and inside institutional investors Filatotchev et al (2000).

\subsection{Group affiliation of business (Keiretsu)}

The Keiretsu is defined as a collective formation of sovereign businesses under joint financial and administrative control of a single person or family. These highly integrated business groups are the established norm in the Japanese business community since the nineteenth century. These vertical and horizontal business networks govern non-publicly owned industrial corporations especially in Japan Khanna and Palepu (2000). According to Wright et al (2005) vertical and horizontal business affiliation might provide mutual benefit to group members through a web of interlocking relationships that can substitute inefficient external markets. The business networks also function as a governance mechanism through their influence on the management of member companies and might prompt the business to start a process of organizational change Hoskisson and Turk (1990), Megginson et al (1994).

However, previous literature regarding restructuring activities argued that business networks are adversely associated with firm's ability to initiate restructuring programs for multiple reasons. First, these business networks may be less receptive to absorb pressure due to inflexibility. The inflexibility and inelastic behavior of member firms reveal that businesses have strong relational links due to mutual debt guarantees, cross-holdings and inside trade Hoskisson and Hitt (1990). Secondly, group reputation, common markets, product transmission channels, internal finance and access to an invisible capital market, can rescue member firms from financial distress. Hence these keiretsu firms might be less sensitive to changes in the competitiveness of the market and regulatory framework. Finally, keiretsu partners quickly rescue a member firm from bankruptcy when it encounters problems of debt accumulation from the main bank Lincoln and Gerlach (2004).

As a result, corporate reforms and economic policies were designed to dismantle business networks and weaken ties among business groups. Japanese policies makers believed that the Keiretsus were the primary reason of the financial crisis in 1997. New commercial codes and corporate laws were formulated after 2006 to pressurize Keiretsus to dissolve group level ties, cross-shareholding and cross debt guarantees were completely discouraged under the new corporate reforms.

Recent government under Abenomics has also reacted strongly against joint moves that facilitate business group formation, setting transfer prices, inside trade and mutual capital support especially in vertical Keiretus. The revitalization strategies required 80 dominated Keiretus to eradicate mutual debt guarantees and joint business moves by the end of 2015. Furthermore, corporate reforms relating to business networks made it quite difficult to realize the ben- 
efits of being a member of keiretsu that hindered the restructuring of poorly performing firms.

\subsection{Main bank system and corporate restructuring}

A detailed examination of the historical evidence of Japanese listed companys' ownership describes that Keiretus have taken total managerial control, particularly in horizontal keiretsus. Under the main bank system, a banker is appointed to the firm's board following poor performance for investigating the causes of cash flow problems rather than lagging share price. However, within bank groups, appointment of bank based directors could influence the company's internal organizational structure to reduce over employment, but cash flow considerations are very central to dependent companies.

Banker appointment in the board may improve the liquidity position of firms to a certain extent but their role in employment decision making is highly suspicious. Bank monitoring is justified to achieve stability in share price but its role in downsizing, rightsizing and cutbacks of perks may cause disloyalty of staff and lower management. Bank based directors can strongly influence the administration of firms though financial incentives Abrahamson and Park (1994).

In the case of Japan, appointment of outside directors has increased the dissatisfaction of shareholders, and dissatisfied investors generally have three tactics to influence the company administration namely voicing opinion, exit, and fidelity Hirschman (1954). Financial institution shareholders, often convey their message to the administration through investor activism. Media campaigns, proxy voting, along with private negotiation with firm management are common ways to establish their presence in the control market Ryan and Schneider (2002). News of substantial selling of shares by major financial institutions can put downward pressure on the firm's share value which can trigger resale of shares causing financial distress. Persistent fall in share value would then force the firm to initiate organizational restructuring. Gillan and Starks (2003), Parrino et al (2003) and Kang and Shivdasani (1997), suggest that the likelihood of restructuring of companies is greater if equity ownership of the firm's main bank is high.

\subsection{Foreign ownership and corporate restructuring}

Since early 1990s, the increasing prominence of international institutional shareholders has directed the corporate sector in Japan towards the Anglo-American corporate governance system. Japanese stock markets were opened for foreign investors with certain restrictions to foster the process of transition from stakeholder to shareholder value maximization. Consequently, portfolio investment by western investors in the Japan Stock Exchange increased from $7.56 \%$ of the overall investment in 1995 to $30 \%$ in 2016 (TSE, 2016).

Recent research argues that foreign institutional investors play a decisive role in disseminating concentrated investment to internal shareholders and in 
supporting the restructuring activities such as rationalizing the resource allocation and employment oriented moves. Foreign institutional investors have a greater impact on share market value than internal shareholders. Under these conditions, risk of exit is an effective way of influencing the management of a Japanese corporation Ahmadjian and Robbins (2005b).

Both local institutional and international stockholders actively provoke the administration to capitalize shareholder benefits by initiating the restructuring process Gillan and Starks (2003). If they find management reluctant to start organizational restructuring they might deploy the threat of aggressive buyouts or support the appointment of outside directors.

In the early 1990s, the financial crisis of Japanese stock markets was one of the events which cautioned sleeping shareholders Johnson et al (2000), La Porta et al (2000), Baek et al (2004). During this time, both domestic and foreign investors realized that their investment is not well protected by the Ministry of Finance $(\mathrm{MoF})$. These considerations initiated substantial withdrawal of portfolio investment and accelerated stakeholder involvement in Japan Baek et al (2004) Rajan and Zingales (1998).

First, we explore the governance factors that have been relatively less studied in previous literature but are gaining more attention in Japan recently; business group affiliation Hoskisson et al (2005), domestic institutional ownership Filatotchev et al (2000) and foreign ownership Ahmadjian and Robbins (2005a). Second, we empirically examine the effect of poor performance of firms on corporate restructuring using a balanced panel data set that consists of Japanese firms data from 1991 till 2015. The change in investment pattern may have significantly influenced corporate restructuring of firms in the Tokyo stock market. Our study can empirically test their effects on corporate restructuring.

\subsection{Corporate restructuring and lifelong employment}

Corporate restructuring is a multi-dimensional process of reshaping diverse aspects of a company in a competitive environment. In the dynamic business environment, it is vital for companies to improve their efficiency and profitability which often requires rebuilding existing organizational systems and structure. Various factors motivate the reorganizing of the company's internal and external setup such as improving market position, survival in adverse economic conditions and diversion towards new business direction. The role of management and ownership is very significant before initiating the process of restructuring as sometimes delayed decision of the management might lead to waste of resources and hurt the achievement of long-term objectives.

Generally corporate acquisitions, takeovers, bankruptcy moves, and buyouts can force the firm towards the restructuring process. During the process of corporate restructuring multiple measures are under consideration by the administration like change in capital expenditure, change in fixed assets and switch to capital intensive or labor intensive productive techniques. The principal-agent model of corporate governance provides the basis for the overall restructuring and improvement of business performance. 
According to the free cash flow theory, the top management invests free cash flow in financially feasible projects having positive net flow. These projects cause over-diversification and organizational inefficiencies Jensen (1986). As free cash flow rises agency costs associated with misappropriation of business also increase and managerial diseconomies of scale force the management to restructure the corporation due to threat of hostile takeover or divestitures.

In the literature on corporate governance three types of corporate restructuring have been identified first, portfolio restructuring involving divestment and acquisitions; second, financial restructuring including stock repurchases, recapitalization and changes in capital structure; third, operational restructuring including reorganization, changes in business strategies and retrenchment. All three classifications of restructuring are interdependent and not mutually exclusive. This research article primarily focuses on firm-level organizational restructuring due to changes in investment pattern and ownership structure. For instance, according to Mitchell and Lehn (1990) Lehn and Poulsen (1989) and Jensen (1986) organizational restructuring is very critical because of its significance for firm's growth orientation and performance.

Symbolically lifetime employment epitomizes Japan's distinctive form of stakeholder capitalism. But lifelong employment does not prevail as the dominant form of employment in Japan. Lifelong employment is not an institution, nor does it constitute a benevolent, kinder method of capitalism associated with the market-based model. A combination of security of employment and flexibility of working practices termed as flexicurity is a common feature of law and practice in Japan.

Is lifelong employment a dying institution in the new corporate governance system? This has become a popular research question among political scientists and economists Dore (2000). The deinstitutionalization of lifelong employment will ensure the end of stakeholder capitalism and confirm the victory of the Anglo-American corporate governance system Ahmadjian and Robinson (2001). Some researchers do not agree with the victory of shareholder-oriented corporate governance practices because recent development in employment practices, such as casualization of the labor force and increasing unemployment do not support the argument of convergence to a market-based corporate governance system.

Since 2006, corporate governance and neo-institutional theories are unable to explain the rapid developments in the labor market and industrial relations in Japan. We need comprehensive research for better understanding of the dynamic change in Japanese legal and economic institutions. We also need new empirical pieces of evidence that can explain the heterogeneous, transient and economic dimensions of corporate governance. However, we try to investigate that is lifelong employment an economic compromise between labor and management in the post-bubble period. This research article argues that a transformation is taking place based on the intensification of existing measures of flexicurity. 


\section{Theoretical framework}

The convergence of traditional group-oriented governance system to the marketbased system and rising role of short-term investors has lasting impact on the investment policy, financial performance and organizational structure. In this section, we build the theoretical and empirical foundations of our research paper.

The study describes that ownership structure is contingent on firm performance and organizational structure. The distinctive goals and asymmetrical information by various class of stakeholders implies that conflict of interest could adversely affect the firm's long-term performance and organizational structure. This section describes the rationale behind the interlocking relationship between firm's performance and corporate restructuring and identifies the linkage between corporate ownership structure and firm's value hypothesis of the study.

\subsection{Corporate restructuring regulatory change and ownership structure}

After the revisions of the commercial code of capital markets in the late 1990s and the early 2000s the process of restructuring was initiated but the composition of ownership is very complex in the diversified majority of listed companies in Japan. Various changes in the law regarding holding companies, stock resale, and repurchases and simplified mergers and acquisition have been effectively introduced by regulatory bodies which have had a significant influence on investment decisions of national and international investors.

The return on investment and profitability ratios are primary indicators of the firm's ability to pay back the shareholders on their investment. The connection between ownership structure and restructuring depends upon the firm's performance that ultimately directs the principals to guide their agents to go for restructuring. Wu et al. (2009) and Wu and Yao (2012) empirically display the systematic relationship between corporate restructuring and financial performance over time. However, the Japanese corporate culture which is based on the concept of community and group-oriented ownership has displayed strong resistance against the government's effort to initiate western style restructuring to enhance economic efficiency.

Moreover, reorganization reform law of 2003 has replaced the old one and new modifications have improved the transparency of business proceedings, information disclosure, collateral of secured rights, mitigation of the majority requirement, fixing of claims, and payment methods etc. These changes have a strong impact on investment strategies of shareholders due to improvement in performance and transparency.

Prior to the enactment of the new law, Japanese companies had to endure federal court inspection before conducting internal restructuring. They were required to obtain individual endorsement from the lenders for the transfer of liabilities and assets that hindered the process of successful corporate restructuring. Now companies can easily choose their optimal corporate structure after the introduction of reorganization reforms law. The implementation of efficient 
organizational structure depends on market conditions and long-term objectives of corporates. Therefore, we expect a negative relationship between the concentrated ownership and organizational restructuring.

\subsection{Ultimate ownership, control transfer, and corporate performance}

The change in decisive ownership and regulatory framework can have positive and negative impact on companies' growth and financial performance. Block holders have greater incentives and opportunities to control business administration as compared to minority shareholders. They can reduce the scale of the agency problem and improve cash flows for all stakeholders by monitoring the behavior of the management Shleifer and Vishny (1991). This would simultaneously maximize profit and decrease value.

Generally, group-oriented capitalists invest in undervalued companies and assert administrative control that would facilitate the pursuit of better performance. Market-based investors are more interested in capital gain due to rise in the current value of shares rather than long term growth of the firm and other commercial ties from the change in ownership. Recently, many studies have analyzed the impact of ownership on firm's value and restructuring activities, Petkova (2008) for India, Girma et al. (2006) for the USA and Conyon et al. (2002) have found a positive impact of ownership.

The empirical evidence of McGuckin and Nguyen (2001) suggests that frequent change in ownership has a negative effect on firm's performance and share market value. But in the case of permanent shareholders takeover, non-financial and financial organizations can stimulate their own benefits at the cost of other shareholders. Moreover, when firms are governed by stable shareholders prior to the change in ownership, the objective of loaning and trade relations remains dominant over economic efficiency.

The above-mentioned studies suggest that change in ultimate ownership has a positive impact on firms' operating and financial performance. We also expect the same directional change in firm value and organizational structure in the Japanese market. It is more likely that the ownership change is positively associated with performance. Therefore, we build the following hypothesis:

Hypothesis (1): Changes in ownership and corporate control are followed by organizational restructuring and improvement in firm value.

\subsection{Ownership concentration, organizational restructuring and firm's value}

According to existing literature, it an established fact that ownership concentration has a positive impact on the firm value and restructuring activities. Usually, concentrated ownership has been assumed to deliver better monitoring incentives and, henceforth, boosts the performance of firms. Diversified ownership creates the problem of a hold-up whereby the owners cannot refrain the managers from constructing their own empires at the expense of the shareholders. The managerial entrenchment problem is also empirically supported by (Fama and Jensen 1983) under which top management can commence value-destroying 
activities with low risk of sanctions or takeovers.

Hence, we conjecture a unidirectional relationship between ownership concentration and firm's value and restructuring ability. Therefore, we construct the following hypothesis:

Hypothesis (2): There is a positive relationship between firm's value and ownership concentration followed by organizational restructuring.

\subsection{Firm value, ownership structure, and organizational restructuring}

The composition of shareholdings in a company determines its ownership structure. How much equity capital is owned by an investor is quite important in explaining the ownership structure of firms in the Japanese stock market. Recent studies have revealed that private individuals and foreign institutional investors are out, waging the dominance of financial institutions and non-financial business shareholders but insiders are yet relevant in the governance of corporations as owners in Japan.

The shareholders' investment choices depend upon available opportunities and their interests and priorities. Conflict of interest among different classes of shareholders is natural because each has their own interest and objective in listed companies. Hence, there is an implicit trade-off between maximization of shareholder wealth and their strategic aims for each class of investors.

In the Japanese corporate control market most accepted identities are inside ownership, financial institutions, non-financial businesses, foreign, family, and government-owned companies. These defined ownership identities have their own distinctive strategic aims regarding firm performance and restructuring process. The shareholdings by financial and non-financial institutions have negative effects on firm performance and restructuring activities due to the dominance of main banks in corporate boards. Furthermore, financing patterns are strongly influenced by Keiretu networks.

Cross-shareholding and cross-debt guaranties have a substantial impact on decision-making regarding the firm's objectives due to the tradeoff between longterm benefits and short-term value maximization of the firm. Hence, we infer that there is a negative impact of financial institutions, cross-holding among the corporations and control transfer to various ownership identities on firm value and restructuring activities. The effect of market-oriented investors like foreign and private domestic shareholders on firm's value is predicted to be positive due to their pursuance of strategic and corporate objectives of optimizing share value in the short term.

Past literature regarding the role of multi-national corporations has confirmed the positive effects of organizational restructuring on firm's performance. This implies that foreign shareholders have strong abilities to monitor management and support performance-based incentives for managers. Moreover, the new ownership structure allows the implementation of the kaizen management style which enables consistent improvement in management practices and the productivity of labor.

Our decomposition of overall ownership into six classifications with respect 
to their strategic objectives in the short run and long run depends upon the financial performance and value maximizing behavior of the management. In the late 2000s, stable rates of profit and more than expected high returns have increased shares prices especially for market-oriented shareholders like domestic private individuals and foreign institutional investors.

Government ownership is not motivated by the profit objective but focuses on playing its strategic role in promoting competition. Blockholders, insiders, and financial institutions also have their own distinct strategic aims and exclusive ownership structure in Japanese firms. Hence, we have developed two hypotheses to explain the predicted relationship between ownership structure and firm's value.

Hypothesis (3A): There is an inverse relationship between ownership control transfer to stable shareholders and firm's ability to engage in restructuring activities.

Hypothesis (3B): There is a direct relationship between control transfer to market-oriented shareholders and firm's profitability and organizational restructuring activities.

A change in capital expenditures and tangible assets are considered as the annual growth of capital expenditures and growth of the book value of fixed assets year by year respectively. The change in fixed assets and capital expenditure are used to evaluate the influence of a change in ultimate owner's assets divestitures. The growth rate of an employee is designed as the growth rate of employment in every firm at the close of the business financial year. These constructed variables serve as the proxy for employee layoffs.

\subsection{Change in firm ownership structure}

The Japanese ownership structure has been robustly examined by several research studies in the last five decades. There has been a remarkable growth in foreign investment with arms-length increase in institutional and domestic investment. According to Aoki (1990) and Colpan et al (2007), the variations in shareholding are directly linked with continuous corporate reforms to achieve the objective of shareholders value maximization and to protect the rights of minority shareholders.

In the last three decades, even strong companies were unable to isolate themselves from business networks due to dissolution of Keiretu ties which has been observed across all firms uniformly Xu and Wang (1999) Inoue (1999). The traditional buyer and supplier relationship has been disintegrating as a result of technological advancement Andrews and Chompusri (2001) and rapid access to quality suppliers has diminished the advantages of Keiretus Miwa and Ramseyer (2005). 
Lincoln et al (1996) La Porta et al (1997) have supported the argument of convergence hypothesis that these changes in the equity market have shifted the corporate control market towards market-oriented investors and the Japanese corporate governance system has increasingly evolved towards the North American ownership arrangements among keiretsu firms. These changes in equity ownership have enhanced the importance of a fresh analysis of the corporate control market.

In this research, we have segregated the whole corporate ownership structure into six classifications and concept of ultimate ownership will facilitate the examination of the effect of performance on firm's equity. These corporate ownership identities are financial firms, non-financial firms, foreign institutional investors, demotics private individuals, government and inside management including employees.

\subsection{Change in ultimate ownership and control variables}

The classification of ultimate owner or decisive owner and transfer of control has been described in two steps for each company. Firstly, the criteria of percentage shareholding is used to identify the ultimate owner of each sample company. If a particular corporate ownership entity possesses 50 percent or more of the total outstanding paid-up capital, it is considered as the ultimate owner of the firm. Secondly, if none of the corporate ownership entity owns at least 50 percent of outstanding shares, then the firm is identified as a diverse company.

After the identification of the ultimate owner the change in ultimate ownership and control transfer is analyzed on the basis of outstanding shares over the same sample period of each ownership classification. If a particular identity was possessing less than 50 percent of total outstanding shares in the previous year but now owns 50 percent or more than this is documented as a control transfer to the ultimate owner.

For the sake of hypothesis testing and to avoid the specification error in the econometric model we have included six firm-specific financial indicators as a control variable which have been extensively reported in previous literature. These control variables might affect the firm's value maximizing behavior as well as its organizational structure. To control for variations and firm-specific heterogeneity we included the firm size, Altman Z-Score, product market industrial share, tangibility and debt-equity ratio. The construction and composition of each control variable is described in table 2 .

\section{Data and sample selection}

Our sample consists of 25 years of longitudinal data from 1991 to 2015 of publicly listed companies from the Tokyo stock exchange which accounts for more than $80 \%$ of Japanese financial market activities. The firms which belong to the financial services industry like insurance companies, mutual funds are excluded from the analysis due to their special capital structure. We have estimated a balanced panel data of 1016 sample companies from the total population of 2440 
Table 2: Summary statistics of the variables

\begin{tabular}{lrrrrrrr}
\hline Variables & Mean & Median & Max & Min & Std. Dev & Skew & Kurtosis \\
\hline Firm size & 4.25 & 4.35 & 6 & 0.01 & 0.73 & -1.44 & 6.87 \\
Z-Score index & 3.49 & 3.43 & 94.48 & -97.03 & 4.92 & -0.76 & 133.503 \\
Market share & 0.37 & 0.17 & 3.99 & 0 & 0.53 & 3.39 & 17.96 \\
Tangibility & 157.65 & 137.903 & 399.9 & 5.75 & 77.25 & 0.88 & 3.29 \\
Debt-Equity ratio & 170.7 & 130.107 & 599.9 & 0.24 & 133.99 & 1.06 & 3.37 \\
Quick ratio & 127.1 & 103.35 & 499.7 & 0.95 & 86.81 & 1.57 & 5.74 \\
TOBIN's Q ratio & 1.5 & 0.81 & 10 & 0.04 & 1.84 & 2.18 & 7.74 \\
Return on assets & 6.35 & 5.31 & 78.89 & -79.6 & 9.73 & -0.05 & 18.88 \\
Growth in sales & 5.99 & 3.74 & 99.98 & -91.55 & 18.97 & 1.03 & 8.37 \\
(GRRP) & & & & & & & \\
Growth in em- & -0.08 & -0.02 & 2.9 & -2.98 & 0.31 & -2.48 & 22.36 \\
ployment (G.E) & & & & & & & 9.84 \\
Efficiency in capi- & 214.94 & 124.8 & 1496 & 0.57 & 259.01 & 2.6 & 9.84 \\
tal exp. & & & & & & & \\
Financial firms. & 0.06 & 0 & 0.71 & 0 & 0.12 & 2.13 & 7.15 \\
Non-Fin firms & 0.1 & 0 & 1 & 0 & 0.18 & 2.09 & 7.12 \\
Foreign investors & 1.08 & 0 & 95.88 & 0 & 4.15 & 9.74 & 147.9 \\
Private individuals & 0.12 & 0 & 1 & 0 & 0.2 & 1.46 & 3.93 \\
Insiders & 3.76 & 0 & 100 & 0 & 9.3 & 3.87 & 25.88 \\
Govt & 0.01 & 0 & 12.86 & 0 & 0.19 & 33.49 & 1489.28 \\
CAT-1 (FIN) & 0 & 0 & 1 & 0 & 0.05 & 19.54 & 382.085 \\
CAT-2 (NFIN) & 0.01 & 0 & 1 & 0 & 0.1 & 9.83 & 97.62 \\
CAT-3 (PFIN) & 0.02 & 0 & 1 & 0 & 0.14 & 6.73 & 46.31 \\
\hline
\end{tabular}

listed companies in the Tokyo Stock Exchange.

Most of the variables are retrieved as they are presented in the financial statements and very few of them are constructed. All information and data are based on the consolidated book of accounts and financial statements to appraise the firm's financial performance and restructuring process throughout the sample period of the study. The values of each variable are taken at the end of the fiscal year. Financial information has been retrieved from the Nikkei Economic Electronic Databank system NEEDS hereafter; that is Handbook and World scope of Japanese companies.

Furthermore, some variables like fixed assets, tangibility, sales growth had extreme values. To deal with such problems $95 \%$ Winsorization transformation* is applied to standardize the data. Winsorized estimators are generally efficient in trimming the outlier and considered robust for regression analysis. Outliers are replaced with average values of a firm so during that process we lost many observations. It is worth mentioning that majority of the control variables and the governance structure variable are based on the author's own calculations. The Z-score is based on the standard formula Altman Specification to predict the bankruptcy or default risk of the firm.

A fixed effect model is estimated to evaluate the empirical evidence from the financial records of a firm level dataset. The Fixed Effect Model is usually applied to the panel dataset because first differencing of the model removes the presence of heterogeneity.

Equation (1) contains the dependent variable $y_{i t}$ for four measures of firm performance and restructuring activities, two for each one. The $\alpha$ the is param- 


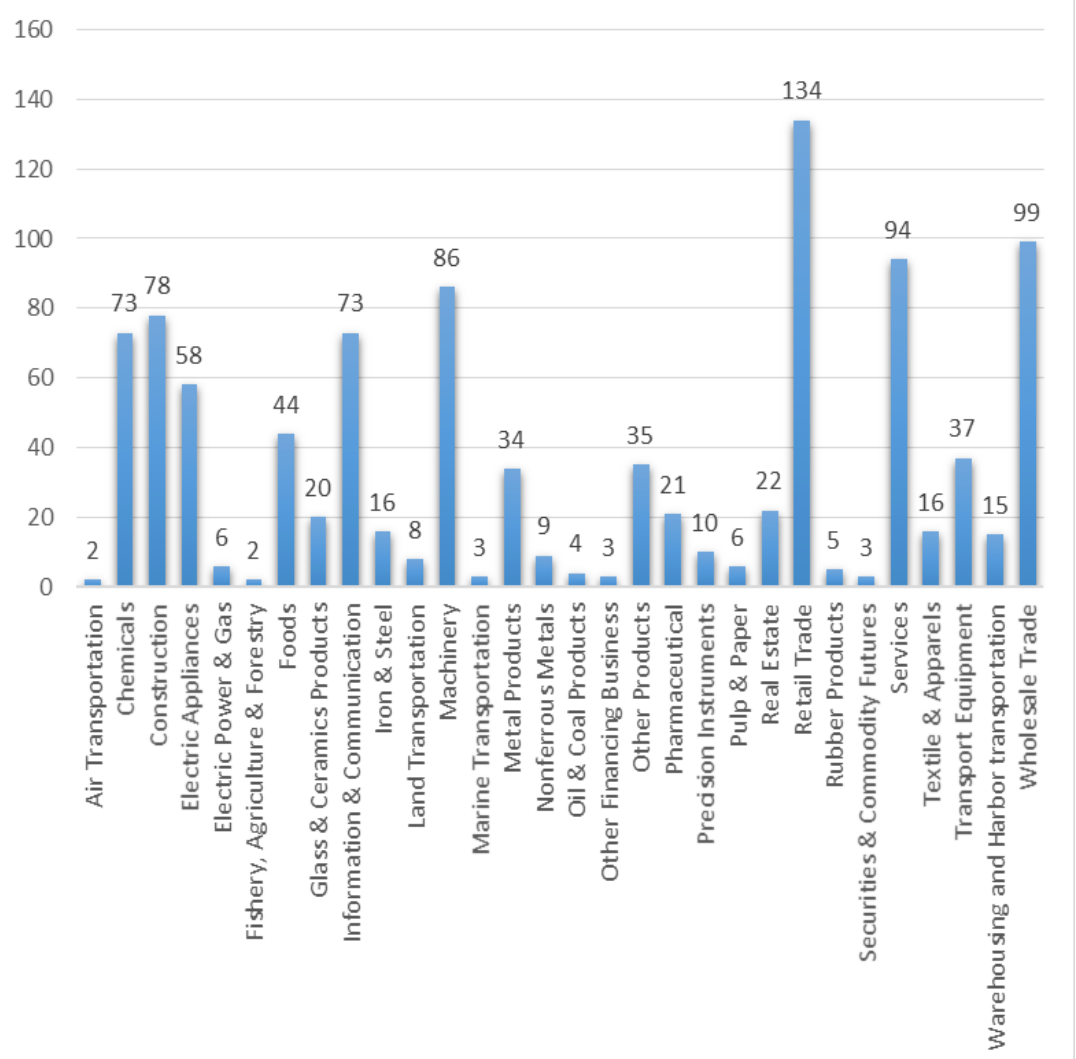

Fig1: Industrial distribution of sample firms listed on Tokyo Stock Exchange

eter to be estimated. The FISH is the ratio of financial institutions ownership, NFISH is the ratio of other corporations' ownership, PISH is the ratio of domestic private individual's ownership and FISH is the share of foreign investors.

$$
\begin{array}{r}
y_{i t}=\alpha_{1} \text { FISH }_{i, t-1}+\alpha_{2} \text { NFISH }_{i, t-1}+\alpha_{3} \text { PISH }_{i, t-1}+\alpha_{4} \text { FISH }_{i, t-1} \\
+\alpha_{5} \text { INDSH }_{i, t-1}+\alpha_{6} \text { GOVTSH }_{i, t-1}+\delta_{1} S I Z E_{i t} \\
+\delta_{2} L E V E R A G E_{i t} \\
+\delta_{3} H I_{i t}+\alpha_{i}+\varepsilon_{i t}
\end{array}
$$

In the second stage of our analysis we estimated the same model, with the inclusion of some additional binary variables. Equation 2 is representing the second model for assessment of the time-lagged impact of ultimate ownership on performance and restructuring activities.

$$
\begin{gathered}
y_{i t}=\alpha_{1} \text { FISH }_{i, t-1}+\alpha_{2} \text { NFISH }_{i, t-1}+\alpha_{3} \text { PISH }_{i, t-1}+\alpha_{4} \text { FISH }_{i, t-1} \\
+\alpha_{5} \text { INDSH }_{i, t-1}+\alpha_{6} \operatorname{GOVTSH}_{i, t-1}+\beta_{0} U C T_{(\tau=0)}+\beta_{1} U C T_{\tau=1}+\beta_{2} U C T_{\tau=2} \\
+\delta_{1} S I Z E_{i t}+\delta_{2} L E V E R A G E_{i t}+\delta_{3} H I_{i t}+\alpha_{i}+\varepsilon_{i t}
\end{gathered}
$$


In the third stage, we further added two lead years of each ownership identity in the same equation to capture the future impact of the change in ownership on the firm's value and restructuring activities. The specification of the model is as follows:

$$
\begin{aligned}
& y_{i t}=\alpha_{1} F_{I S H_{i, t-1}}+\alpha_{2} \text { NFISH }_{i, t-1}+\alpha_{3} \text { PISH }_{i, t-1}+\alpha_{4} F I S H_{i, t-1} \\
& +\alpha_{5} \operatorname{INDSH}_{i, t-1}+\alpha_{6} \operatorname{GOVTSH}_{i, t-1}+\beta_{1} \operatorname{FIT}_{(\tau=0)}+\beta_{2} \text { FIT }_{\tau=1}+\beta_{3} F I T_{\tau=2} \\
& +\beta_{4} \operatorname{NFIT}_{(\tau=0)}+\beta_{5} \operatorname{NFIT}_{\tau=1}+\beta_{6} \operatorname{NFIT}_{\tau=2}+\beta_{7} \operatorname{PFIT}_{(\tau=0)}+\beta_{8} \operatorname{PFIT}_{\tau=1} \\
& \quad+\beta_{9} \operatorname{PFIT}_{\tau=2}+\delta_{1} \operatorname{SIZE}_{i t}+\delta_{2} L E V E R A G E_{i t}+\delta_{3} H I_{i t}+\alpha_{i}+\varepsilon_{i t}
\end{aligned}
$$

Initially, we employed the Hausman (1978) specification to establish the relationship between the explanatory variables and firm-specific effect. The Hausman test is usually used as a benchmark method to assess the appropriateness of estimated parameters with fixed effects or random effects formulation.

Table 6 presents the computed chi-square values which imply that the firmspecific effects are correlated with the explanatory variables. The random effects estimates are not appropriate because of the high probability of a correlation that can produce significant biases in estimates. Hence, fixed effects models seem more suitable for the estimation of equation (1) to (3) to assess the nature and direction of a relationship between the ownership structure and firm's value and restructuring activities.

Finally, we estimate the fixed effects model specification for the above three equations for all the dependent variables. The results of multivariate models (FEM) to evaluate the relationship between the dependent variables and explanatory variables for the impact of ownership structure and control variables are presented in table $5 \& 6$.

Table 3: Summary of key ultimate ownership transfers

\begin{tabular}{llr}
\hline Variables & Description & Firms \\
\hline$(\mathrm{UCT}=1)$ & Firms experience change in control & 847 \\
$(\mathrm{UCT}=0)$ & Firms that do not experience change in control & 169 \\
N & Total firms included in sample & 1016 \\
FIT & Transfer of ultimate control to financial institutions & 66 \\
NFIT & Transfer of ultimate control to non-financial institutions & 255 \\
PFIT & Transfer of ultimate control to private individuals or for- & 526 \\
& eign corporations & \\
\hline
\end{tabular}

Note: FIT, NFIT and PFIT are variables indicating the transfer of ownership to financial institutions, non-financial corporations and private individuals respectively.

\section{Multivariate and univariate results}

This section presents empirical outcomes of the subsequent transfer of corporate control and change in ultimate ownership on performance and on the extent of organizational restructuring. Section 5.1 presents the univariate descriptive analysis and section 5.2 reports the results of the multivariate model. 


\subsection{Univariate empirical results}

In the univariate analysis, we examine whether companies that experience a change in decisive ownership in any sample year perform better than firms that do not experience such change. For the firm with control transfer to various ownership identities, the measure of central tendencies (mean and median) of the various measures of firm values and organizational restructuring are calculated for the year prior to control transfer (year -1), for the year of the change in control (year 0) and in the following two years (year 1 and year 2) for the sake of compression of the average performance in various years. For the firms, without control transfer, the calculated figures are for the entire sample years.

The results for two different measures of firms' performance are provided in table 4 . The empirical results suggest that the growth in sale revenue rises from $8.023 \%$ to $7.71 \%$ in the year of change in control. In the two post change years, it rises significantly to $7.625 \%$ in the first year and to $7.71 \%$ in the second year. In the year prior to change, the sales growth is lower than $8.023 \%$ for the firm without the change in control, however, in the year of change and in the following two years, it is higher than the growth of sales revenue of firms in which ownership does not change.

Similarly, the Tobin's Q ratio increases by $11.192 \%$ in the year of change in control which is significantly higher than $7.192 \%$ in the year prior to the change. Prior to the change in ownership, the average market performance indicated by Tobin's Q ratio of firms with a change in control is approximately $9.322 \%$ higher than $7.192 \%$ for firms that do not experience a change in ownership. However, it is significantly lower than the $13.111 \%$ in the year of change and $15.041 \%$ in the following two years for the firm without the change in control.

Overall the results of univariate analysis reveal that the performance in the year prior to the change for firms with the change in control is higher than the average performance of firms without a change in ownership for both the measures of performance. The results are consistent with our earlier expectations and lead to the acceptance of our first hypothesis. The results suggest that new ultimate owners are opting for their disciplinary role in the firms which results in improvement in profitability and average performance.

In order to evaluate the impact of the change in control on the extent of organizational restructuring activities, the univariate results are presented in table 4. Capital expenditures have increased significantly in the year of change and in two subsequent years after the change in control. The growth in capital expenditures increased from $23.794 \%$ in the year prior to the change, to $26.307 \%$ in the year of change, among the firms that experience change in ownership. The growth in capital expenditure in the year prior to the change is higher than that of the firms without a change in control but is significantly lower than $26.309 \%$ in the year of change and in the following two years.

Furthermore, firms with a change in control experience significant expansion in the book value of fixed assets following change in control. The fixed assets growth rate increased from $4.841 \%$ a year prior to change to $4.160 \%$ in the year of change within the group of firms with a change in ownership, but in the subsequent two years it falls again to $2.914 \%$. The growth rate, in the year of 
change in control, is almost same at $4.253 \%$ for the firms that do not experience such a change. The results show that, while fixed assets increase following a change in control, this increase is still lower than the average growth rate of fixed assets for firms that do not experience a change in ownership.

Overall the results of the univariate analysis reveal that new ultimate owners enforce their control strongly and major restructuring activities take place to alter and reshape the organizational assets and structure in order to pursue their ultimate objectives.

Table 4: Univariate results of the impact of change in corporate control

\begin{tabular}{|c|c|c|c|c|c|}
\hline Variables & Period & No chg in control & Obsv & Chg in control & Obsv \\
\hline \multicolumn{6}{|c|}{ Growth in revenue } \\
\hline & Year $(-1)$ & & & 8.023 & 9075 \\
\hline & Year $(0)$ & 7.545 & 653 & 6.775 & 737 \\
\hline & Year (1) & & & 7.625 & 847 \\
\hline & Year (2) & & & 7.71 & 785 \\
\hline \multicolumn{6}{|c|}{ Tobin's Q ratio } \\
\hline & Year $(-1)$ & & & 7.322 & 9075 \\
\hline & Year $(0)$ & 10.192 & 653 & 14.1923 & 737 \\
\hline & Year (1) & & & 15.111 & 847 \\
\hline & Year (2) & & & 16.041 & 785 \\
\hline \multicolumn{6}{|c|}{ Growth in capex } \\
\hline & Year $(-1)$ & & & 16.516 & 9075 \\
\hline & Year $(0)$ & 18.751 & 653 & 23.423 & 737 \\
\hline & Year (1) & & & 24.794 & 847 \\
\hline & Year (2) & & & 26.309 & 785 \\
\hline \multicolumn{6}{|c|}{ Growth in F. assets } \\
\hline & Year $(-1)$ & & & 4.84 & 9075 \\
\hline & Year $(0)$ & 4.16 & 653 & 4.253 & 737 \\
\hline & Year (1) & & & 4.16 & 847 \\
\hline & Year (2) & & & 4.114 & 785 \\
\hline \multicolumn{6}{|c|}{ Growth in emp } \\
\hline & Year $(-1)$ & & & -1.07 & 9075 \\
\hline & Year $(0)$ & -1.069 & 653 & -1.869 & 737 \\
\hline & Year (1) & & & -1.067 & 847 \\
\hline & Year (2) & & & -1.063 & 785 \\
\hline
\end{tabular}

\subsection{Multivariate empirical results}

Examining the effect of ultimate ownership conveys very important information. The signs and statistical significance of the regression coefficients are stable for the various measures of firms' performance and restructuring activities but, there are marked differences in the magnitude of the impact of the explanatory variables on the performance and restructuring measures. In order to test the hypotheses, we broadly focus on the relationships between firm performance and ownership structure.

The empirical results of multivariate models put forward two important messages regarding the impact of ultimate ownership and control transfer on 
firm's value and restructuring activities. First, the sign and statistical significance are consistent with univariate results for the four dependent variables. But the magnitude of the estimated coefficients in multivariate models exhibits marked differences. Second, the significance of multivariate results is based on regression analysis and effectiveness of robust techniques. Our primary focus is to assess the impact of ownership structure and control transfer on the firm's value and restructuring activities.

Table 5: Empirical findings of ownership structure, corporate performance and restructuring activities

\begin{tabular}{|c|c|c|c|c|}
\hline \multirow[b]{2}{*}{ Dependent Variable } & \multicolumn{2}{|c|}{ Firm performance } & \multicolumn{2}{|c|}{ Restructuring activities } \\
\hline & Tobin's Q & ROAP & GRE & $\mathrm{ECE}$ \\
\hline \multirow[t]{2}{*}{ Firm size } & $0.827^{*}$ & $-13.840^{*}$ & 0.0876 & $537.229 *$ \\
\hline & $(0.003)$ & $(0.215)$ & $(0.136)$ & $(1.593)$ \\
\hline \multirow[t]{2}{*}{ Z-score } & $-0.003^{*}$ & $0.040^{*}$ & $0.001^{*}$ & 0.009 \\
\hline & 0 & $(0.006)$ & 0 & $(0.097)$ \\
\hline \multirow[t]{2}{*}{ Product market share } & $-0.095^{*}$ & $-3.920^{*}$ & 0 & $191.35^{*}$ \\
\hline & 0 & $(0.014)$ & $(0.393)$ & $(0.405)$ \\
\hline \multirow[t]{2}{*}{ Tangibility } & $-0.001^{*}$ & $-0.060 * *$ & 0.0229 & $3.348^{*}$ \\
\hline & 0 & $(0.001)$ & $(0.018)$ & $(0.012)$ \\
\hline \multirow{2}{*}{ Leverage } & $-0.001^{*}$ & $-0.120^{*}$ & 0.001 & $5.804^{*}$ \\
\hline & 0 & 0 & $(0.016)$ & $(0.013)$ \\
\hline \multirow[t]{2}{*}{ Quick ratios } & $-0.004^{*}$ & $-0.200^{*}$ & -0.002 & $9.126^{*}$ \\
\hline & 0 & $(0.001)$ & $(0.005)$ & $(0.02)$ \\
\hline \multirow[t]{2}{*}{ Non Fin } & $33.413^{*}$ & $1558.45^{*}$ & $0.716^{*}$ & $-73504.2^{*}$ \\
\hline & $(0.055)$ & $(5.086)$ & $(0.062)$ & $(154.248)$ \\
\hline \multirow[t]{2}{*}{ Govt } & $-0.054^{*}$ & -0.26 & -1.832 & -563.35 \\
\hline & $(0.019)$ & $(0.261)$ & $(140.873)$ & $(250.52)$ \\
\hline \multirow[t]{2}{*}{ Inside } & 0.033 & 0.2 & $3.7^{*}$ & 15.645 \\
\hline & $(0.022)$ & $(0.295)$ & $(0.575)$ & $(20.66)$ \\
\hline \multirow[t]{2}{*}{ Prvt } & -0.008 & -0.18 & 164.4 & -10.745 \\
\hline & $(0.017)$ & $(0.236)$ & $(528.754)$ & $(13.58)$ \\
\hline \multirow[t]{2}{*}{ FIN } & $0.009^{*}$ & 0.01 & $-648.3^{*}$ & 6.145 \\
\hline & $(0.005)$ & $(0.061)$ & $(73.403)$ & $(8.31)$ \\
\hline \multirow[t]{2}{*}{ Forn } & -0.001 & 0.01 & 0.063 & 4.145 \\
\hline & $(0.001)$ & $(0.01)$ & $(0.035)$ & $(10.71)$ \\
\hline J-stat (P-value) & 0.395 & 0.318 & 0.538 & 0.138 \\
\hline $\begin{array}{l}\text { Lag: } 2 \text { Serial Corr. (P- } \\
\text { value) }\end{array}$ & 0.082 & 0.024 & 0.004 & 0.038 \\
\hline
\end{tabular}

Note: This table reports the finding of the Fixed Effect Model regression estimates of the left-hand side variables growth in sale revenue (GRRP), TOBINS-Q (TOBIN), growth in capital expenditures (GCE), and growth rate in employment (GRE). Standard errors are in parenthesis. $*, * *$ and $* * *$ indicate that individual coefficients are statistically significant at the $0.10,0.05$ and 0.01 level of significance respectively. The number of observations is 24500 .

\subsection{Ownership structure and firm value}

The results in table 6 show the impact of ownership structure on firm performance and restructuring activities. First, we observe that leverage has a statistically significant effect on corporate performance. According to table 6, empirical 
results of the multivariate model suggest that a strong relationship exists between the various measures of firm's performance and corporate restructuring in the short and medium run. The impact of ownership structure and ultimate ownership initially have an unclear impact on performance and restructuring but gradually improve the firm's value and support the hypothesis regarding the restructuring process in the sample firm.

The estimated parameters of multivariate regression support the theoretical view regarding the disciplinary role of newly placed ownership Jensen (1986). Moreover, the dummy is negatively related to dependent variables of firm value while positively related to organizational restructuring.

The ownership identities have an impact on firm's value as well as on the restructuring activities due to strong intervention in decision making and operational function by the newly replaced ownership of companies. The impact on the shareholding ratio is statistically significant for both financial and nonfinancial firms. This particularly holds for the ownership identities of nonfinancial firms that have a more powerful influence on the management and is able to insulate them from outside involvements.

Multivariate results also indicate that high stabilized ownership can isolate management from outside pressures. Furthermore, the impact of shareholding on restructuring activities is not clear for both financial and non-financial institutions. Financial sector ownership has a negative influence on the progressive rate of employment and no statistical substantial effect on the efficiency of capital expenditures, while shareholding by other affiliated firms has statistically significant effect on expansion in terms of growth in employment.

The market-oriented ownership identities have a significantly negative influence on both measures of firm value and are positively related to the extent of growth in capital expenditures. However, the growth in employment is unaffected by shareholding by domestic individuals or foreign institutions. This suggests that foreign and private ownership identities have a strong influence on management related decision-making practices in Japanese firms and the role of market investors is consistently associated with high performance and an increase in efficiency.

Inside ownership as characterized by managers and employees has a positive effect on firm value and on restructuring activities in the firm except for growth in capital expenditures. Furthermore, government shareholding does not have a negative impact on performance measures, proxies of restructuring activities, growth in employment and capital expenditures. The control variables are consistent with the theoretical relationship of performance indicators and proxies of restructuring activities.

The Z-score has a significant negative effect on firm's market value indicator Tobin's Ratio, but positive and statistically significant effect on ROAP due to risk free expectation of profit by investors. It shows positive and statically significant relationship with growth in employment and insignificant but positive relationship with efficiency of capital expenditure. The impact of tangibility and Quick Ratio observed on both performance indicators are negative and statistically significant, but the quick ratio has a negative and insignificant effect on growth rate of employment and a positive and significant effect on efficiency of 
capital expenditure.

The Product Market Industrial share (INDS) is an indicator of competition which is also added to the control variables to assess the firm's competitiveness in its particular industrial sector. The sign and magnitude of the industrial share confirms the adverse impact of competition on firm's performance. The constructed variable INDS has a negative and significant impact on both performance measures, Tobin's Q Ratio and Return on Assets and its impact on restructuring activities is not worth standing.

5.4 Corporate restructuring, firm value and ultimate change in ownership

Equation (2) is regressed to evaluate the influence of a change in ultimate control, and the results of FEM are presented in table 6. The impact of control variables and governance structure is similar to the outcomes of table 5 in terms of statistical significance and sign, though there is trivial variation in degrees (results not reported in table 6). The estimates of the model regarding control transfer also confirm our former expectations. The coefficient of the first and second period after the control transfer is affirmative and substantial for both measures of firm value and restructuring activities.

The results regarding the ROAP indicate that the return on assets improves in the first and second year after the change in control as the estimated effect is positive and highly statistically significant. The estimated coefficient of $U C T_{\tau=0}$ (the year of change in control) is positive with $10 \%$ level of significance.

Regarding the market measures of corporate performance, the results reveal that Tobin's Q ratio increases at all the points in time since the event occurs. The impact on ROAP is almost same in the first two periods. The impact of the

Table 6: Impact of control transfer on firms' value and restructuring activities

\begin{tabular}{lllll}
\hline & \multicolumn{2}{c}{ Firm performance } & \multicolumn{2}{c}{ Restructuring activities } \\
\hline Dependent Variable & Tobin's Q & ROAP & ECE & GRE \\
\hline$U C T_{\tau=0}$ & $0.309^{*}$ & $0.071^{*}$ & 8.318 & 0.025 \\
& $(0.112)$ & $(0.021)$ & $(5.962)$ & $(0.009)$ \\
$U C T_{\tau=1}$ & $0.094^{*}$ & $0.016^{*}$ & -3.474 & $0.004^{*}$ \\
& $(0.07)$ & $(0.006)$ & $(3.124)$ & $(0.004)$ \\
$U C T_{\tau=2}$ & $0.198^{*}$ & $0.002^{*}$ & 0.87 & 0.008 \\
$R^{2}$ & $(0.06)$ & $(0.003)$ & $(2.079)$ & $(0.002)$ \\
Adj- $R^{2}$ & 0.404 & 0.942 & 0.988 & 0.196 \\
S.E.of regression & 0.379 & 0.939 & 0.9875 & 0.161 \\
F-statistic & 15.404 & 0.553 & 97.4841 & 0.279 \\
F-stat(P-value) & 16.006 & 382.18 & 1943.659 & 5.734 \\
\hline
\end{tabular}

Note: The table reports results of the fixed effects two stages least square (FE-2SLS) model of the dependent variables return on assets (ROAP) and Tobin's Q ratio (TQR). The detailed definition of the estimated model is given in equation (3) and (6). Both the estimations include time control (not reported). The LM serial corr. test (P-value) is the probability value of the Breusch-Godfrey serial correlation test of order 2. The Null hypothesis is that the second order residuals correlation is zero. ${ }^{*}, * *$ and $* * *$ indicate that the coefficients are statistically significant at the $0.10,0.05$ and 0.01 level of significance respectively. 
change in ultimate ownership on the extent of restructuring activities at various points of time show that the efficiency of capital expenditure rises in the year of change in control and in the second year after the change, however, the estimated effect is greater in the first fiscal year. This suggests that restructuring activities are taken into account by the new ownership for enrichment of their own strategic objectives.

Regarding restructuring activities measured in terms of growth rate in employment in the firm, there is significant difference in growth rate of employment in firms which experience a change in control and those that do not experience such a change. However the employment level declines with the passage of time after the year of change in ultimate ownership.

The results propose that the firm value, either specified as book value or market value, improves in two years after the change in ultimate ownership. Control transfer is followed by restructuring activities in terms of rise in efficiency in capital expenditure, contraction in growth of fixed assets and gradual fall in employment level.

\subsection{Transfer of control to various corporate entities and firm performance}

To market valuation amongst the transfer to different corporate entities, equation 3 is estimated, which accounts for the information regarding the transferred parties, by employing the FEM. The estimated equation includes all the control and governance structure variables along with the ownership transfer to various corporate entities considered as dummy variables. Table 7 presents the results for the impact of the ownership change to various entities observed at three distinct periods.

The impact of debt and equity and ownership explanatory variables are analogous to the results presented in table 6 in terms of statistical significance and sign, except for some minor variation in the scales of the said variables. The results disclose the impact of change in ownership on performance measures and restructuring activities among various ownership identities.

Tobin's ratios improve in the first and second year after the change in control and are statistically significant for FIT transfers. The impact of financial institution transfers in the year of control transfer can be seen by the negative sign and the magnitude of financial institution control transfers (FIT). Tobin's Q falls in the year prior to control transfer for non-financial institutions (NFIT) and improves in the year of control transfer which is highly statistically significant. After that it consistently falls for both years after the change in control.

There is a statistically significant impact of private-financial institution transfers in the year of control transfer and in the prior year, but the relationship is negative in all the four years. This is consistent with corporate governance literature as market oriented shareholders are not interested in long-term corporate policy and planning.

Sales growth improves only in the first year after the control transfer but is statistically insignificant in the current year and year after PFIT transfers. The impact of control transfer on ROAP, rises in the next two years after the con- 
Ownership structure changes...

Table 7: Results of various corporate entities and control transfers

\begin{tabular}{|c|c|c|c|c|}
\hline \multirow{2}{*}{$\begin{array}{l}\text { Conditional fixed ef- } \\
\text { fects estimates } \\
\text { Dependent Variable }\end{array}$} & \multicolumn{2}{|c|}{ Firm performance } & \multicolumn{2}{|c|}{ Restructuring activities } \\
\hline & Tobin's Q & ROAP & $\mathrm{ECE}$ & GRE \\
\hline$F I T_{\tau=-1}$ & $\begin{array}{c}0.069^{* *} \\
(0.039)\end{array}$ & $\begin{array}{c}-0.021 * \\
(0.535)\end{array}$ & $\begin{array}{c}3.245 \\
(8.597)\end{array}$ & $\begin{array}{l}-0.015 \\
(0.031)\end{array}$ \\
\hline$F I T_{\tau=0}$ & $\begin{array}{c}-0.144^{*} \\
(0.04)\end{array}$ & $\begin{array}{c}0.328^{* *} \\
(0.552)\end{array}$ & $\begin{array}{l}-4.045 \\
(8.873)\end{array}$ & $\begin{array}{l}-0.002 \\
(0.028)\end{array}$ \\
\hline$F I T_{\tau=1}$ & $\begin{array}{l}0.097^{*} \\
(0.0420\end{array}$ & $\begin{array}{c}0.461^{*} \\
(0.58)\end{array}$ & $\begin{array}{c}3.945 \\
(9.326)\end{array}$ & $\begin{array}{l}-0.016 \\
(0.033)\end{array}$ \\
\hline$F I T_{\tau=2}$ & $\begin{array}{c}0.034 \\
(0.045)\end{array}$ & $\begin{array}{l}0.282^{*} \\
(0.614)\end{array}$ & $\begin{array}{c}7.744 \\
(9.874)\end{array}$ & $\begin{array}{l}0.081^{*} \\
(0.016)\end{array}$ \\
\hline$N F I T_{\tau=-1}$ & $\begin{array}{l}-0.112 \\
(0.021)\end{array}$ & $\begin{array}{c}0.182 \\
(0.294)\end{array}$ & $\begin{array}{c}7.345^{* * *} * \\
(4.724)\end{array}$ & $\begin{array}{c}0.012 \\
(0.017)\end{array}$ \\
\hline$N F I T_{\tau=0}$ & $\begin{array}{l}0.016^{*} \\
(0.022)\end{array}$ & $\begin{array}{l}0.688 \\
(0.31)\end{array}$ & $\begin{array}{c}10.445^{*} \\
(4.98)\end{array}$ & $\begin{array}{l}-0.035^{*} \\
(0.015)\end{array}$ \\
\hline$N F I T_{\tau=1}$ & $\begin{array}{l}-0.021 \\
(0.023)\end{array}$ & $\begin{array}{c}0.503^{*} \\
(0.32)\end{array}$ & $\begin{array}{c}-10.945^{*} \\
(5.149)\end{array}$ & $\begin{array}{c}0.01 \\
(0.016)\end{array}$ \\
\hline$N F I T_{\tau=2}$ & $\begin{array}{l}-0.021 \\
(0.022)\end{array}$ & $\begin{array}{c}0.325 \\
(0.309)\end{array}$ & $\begin{array}{c}11.244^{*} \\
(4.972)\end{array}$ & $\begin{array}{c}0.030^{* * * *} \\
(0.012)\end{array}$ \\
\hline$P F I T_{\tau}=-1$ & $\begin{array}{l}-0.051^{*} \\
(0.016)\end{array}$ & $\begin{array}{c}0.046 \\
(0.218)\end{array}$ & $\begin{array}{l}-2.245 \\
(3.499)\end{array}$ & $\begin{array}{c}0.014 \\
(0.012)\end{array}$ \\
\hline$P F I T_{\tau=0}$ & $\begin{array}{c}-0.27^{* * *} \\
(0.017)\end{array}$ & $\begin{array}{c}-0.740^{*} \\
(0.228)\end{array}$ & $\begin{array}{l}-3.145 \\
(3.673)\end{array}$ & $\begin{array}{l}0.015^{*} \\
(0.012)\end{array}$ \\
\hline$P F I T_{\tau=1}$ & $\begin{array}{l}-0.001 \\
(0.017)\end{array}$ & $\begin{array}{l}-0.272 \\
(0.228)\end{array}$ & $\begin{array}{c}-6.550^{*} \\
(3.663)\end{array}$ & $\begin{array}{c}0.025 \\
(0.011)\end{array}$ \\
\hline$P F I T_{\tau=2}$ & $\begin{array}{l}-0.009 \\
(0.015)\end{array}$ & $\begin{array}{c}-0.485^{*} \\
(0.208)\end{array}$ & $\begin{array}{l}5.510^{*} \\
(3.347)\end{array}$ & $\begin{array}{l}0.024^{*} \\
(0.017)\end{array}$ \\
\hline$R^{2}$ & 0.97 & 0.791 & 0.33 & 0.25 \\
\hline $\mathrm{Adj}-R^{2}$ & 0.97 & 0.791 & 0.329 & 0.236 \\
\hline S.E. of regression & 3864.18 & 2824.19 & 367.019 & 257.261 \\
\hline F-statistic & 0 & 0 & 0 & 0 \\
\hline F-stat (P-value) & 0.97 & 0.791 & 0.33 & 0.25 \\
\hline
\end{tabular}

Note: The table reports results of the fixed effects model of the dependent variables return on assets (ROAP), Tobin's Q ratio (TQR), Growth in capital expenditure (ECE) and Growth in employment(GRE) . The detailed definition of the estimated model is given in equation (3) and (5). Both the estimations include time control (not reported). The LM serial corr. test (P-value) is the probability value of the Breusch-Godfrey serial correlation test of order 2. The Null hypothesis is that the second order residuals correlation is zero. $*, * *$ and $* * *$ indicate that the coefficients are statistically significant at the $0.10,0.05$ and 0.01 level of significance respectively.

trol transfer and is highly statistically significant at $1 \%$ in case of FIT transfers, but it falls before control transfer to financial institutions. This indicates that the role of financial institutions and the main bank impacts firm performance indirectly.

For the NFIT transfers, the return on stocks improve in all the four years but are statistically significant in the first two years after the control transfer. The results for non-financial institutional transfers are mixed. The impact on stock returns is positive in the first and second period after the transfer of ownership to non-financial institutions but is not clear in the year of ownership transfer.

The results of PFIT indicate that in case of ROAP, the performance of the firm is constantly declining in the year of control transfer to private and foreign 
shareholders. This almost confirms the adverse impact on performance as indicated by Tobin's Q ratio.

The results of change in ultimate ownership of the impact of changeovers in different corporate entities, compared with firms that do not experience such a change in control show that efficiency of capital expenditures rises in the following two years after the change in control for financial institutions and non-financial institutions control transfers, except for the year of control transfer. The sign and magnitude of FIT and NFIT in the year of control is negative and statistically significant. We discover a progressive relationship between restructuring activities and ownership transfer to any of the three ownership entities particularly when restructuring activities are measured in terms of capital expenditures. However, the estimated impact is higher in magnitude and significance for the FIT and NFIT transfers than the transfers to private individuals. The results are stable and subsequently resemble the free-cash-flow theory of Shleifer and Vishny (1991).

Both financial and non-financial institutions can be promoted in different ways through huge capital expenditures made by their allied business identities. The rise in capital expenditures in firms that experience transfer to financial and non-financial institutions can promote other marketable and non-equity ties within the firm. The affiliated institutions may benefit from these expenditures on either the buying or the supplying side of a trade relationship Charkham (1994). The employment level is affected by all the three transfers at these three points in time. We find a negative relationship between restructuring activities and ownership transfer to FIT prior to and in the first year after control transfer but a positive and statistically significant relationship in the second year.

The estimated relationship between growth in labor force and non-financial institutions is observed positive and insignificant except in the year of control transfer. In the year of control transfer, it is negative and statistically significant. This implies that internal downsizing and right-sizing of the workforce is adversely associated with transfer of control to non-financial institutions. The direction of the relationship with growth in labor remains positive but is statistically significant in the year of control transfer and in the second year in case of PFIT. This suggests that conversion from labor intensive to capital intensive technology is a long-term activity and needs sufficient lag interval to be considered.

The results presented in table 7 describe the provocative fact that there is a direct relationship between domestic private investors and change in ultimate ownership but the relationship is negative with weak statistical significance for financial and Keiretus firms. The results also confirm the negative relation between the control transfers to financial institutions and non-financial business identity (Keiretus).

Corporate ownership can thus insulate managers from external pressure and promote business value and efficiency. Furthermore, it suggests developing longterm ties rather than monitoring the role of the corporate identities. Interestingly in case of firm efficiency and value, results suggest that coefficients of PFIT are negative and statistically significant. Non-financial firms have a negative re- 
lationship between restructuring and firm's performance indicators.

The sales growth improves only in the first year after the change in control but is statistically insignificant in the current and second period for the PFIT transfers. For financial institution transfers the sales revenue falls in all three periods but the fall in the second year after the change is much larger than the preceding two years. There is no statistically significant impact of non-financial institution transfers in all the three periods.

The ROAP, rises only for the year of change in case of PFIT transfers but is unaffected in the subsequent two periods for the private transfers. For the FIT transfers, the return on stocks improve in the first period but fall in the subsequent two periods after the change in ultimate ownership. Results regarding the non-financial institutional transfers are mixed. The impact on stock returns is negative in the first period and positive in the second period after the transfer of ownership to non-financial institutions but is unaffected in the year of ownership transfer.

The results of control transfer in various corporate entities on restructuring activities compared with firms that do not experience such a change in control show that efficiency on capital expenditures rises in the following two years after the change in control for all the three transfers except for the year of transfer to private individuals, where it is negative and statistically significant. The impact on growth rate in fixed assets is positive in the years after the change in ownership for FIT and NFIT and the firms experience contraction in fixed assets growth for the PFIT. Regarding the employment level, it is unaffected by all the three transfers at all the three points in time. This suggests that conversion from labor intensive to capital intensive technology is a long-term activity and needs sufficient lag interval to be considered.

\section{Summary and Conclusion}

Corporate reforms in Japan has significantly influenced both the performance and organizational restructuring of listed companies. There are sufficient evidences and findings which support the argument regarding sensitivity of firms towards reforms because of the market oriented corporate governance mechanism. The financial deregulation and corporate reforms have resolved the agency problem and promoted equity markets which has profoundly weakened the bankcentered system.

Our empirical findings presents a fresh analysis regarding the impact of governance on firm's performance and restructuring activities. Ownership structure and control transfer are positively associated with firm value and organizational restructuring on the listed companies of TSE. Our panel data estimates are consistent with the hypothesis that both the restructuring process and firm value are profoundly associated with reforms and the corporate governance system.

Our results have key significance as they can guide policy makers after the controversial completion of Abenomics policies in Japan. There are many inferences that can be used as a source of direction. First, the market oriented shareholders still hold lesser proportions of equity then stable shareholders but 
their equity positions have been increasing after the introduction of market oriented governance system. This indicates that the collective impact of ownership transfer to private individuals and foreign institutional shareholders will improve firms' efficiency and the payoffs for minority shareholders.

Secondly, the introduction of independent directors and the new law of information disclosure has reduced agency costs and has positive effects on firm value and restructuring activities. Furthermore, control transfer to the government does not have any impact on firm performance and value. The results also provide vibrant indications that the change in control is followed by improvement in efficiency and performance.

Lastly, we find that there is an indirect relationship between firm's performance and control transfer to financial institutional shareholders which suggests that unwinding the cross-shareholding between banks and corporations causes efficiency loss. But financial firms still have significant equity position in listed companies. Moreover, control transfer to Keiretus based shareholdings have a significant negative impact on restructuring activities and firm performance. This means that group oriented benefits can only be ripe in times of high performance otherwise profit making firms will prefer to unwind their cross-holdings. Thus, Japanese corporations are building business relationships with high performance firms and looking towards business diversification, both in the product and capital market.

\section{References}

Abrahamson E, Park C (1994) Concealment of negative organizational outcomes: An agency theory perspective. Academy of management journal 37(5):1302-1334

Ahmadjian CL, Robbins GE (2005a) A clash of capitalisms: Foreign shareholders and corporate restructuring in 1990s japan. American Sociological Review 70(3):451-471

Ahmadjian CL, Robbins GE (2005b) Stability and change in embedded relationships: Broken ties in Japanese automotive keiretsu. 239, Center on Japanese Economy and Business, Columbia Business School

Ahmadjian CL, Robinson P (2001) Safety in numbers: Downsizing and the deinstitutionalization of permanent employment in japan. Administrative Science Quarterly 46(4):622-654

Ahmadjian CL, Song J (2004) Corporate governance reform in japan and south korea: Two paths of globalization. Center on Japanese Economy and Business Working Paper 221

Andrews TG, Chompusri N (2001) Lessons in cross-vergence: Restructuring the thai subsidiary corporation. Journal of International Business Studies 32(1):77-93

Aoki M (1990) Information, incentives and bargaining in the Japanese economy: a microtheory of the Japanese Economy. Cambridge University Press

Baek JS, Kang JK, Park KS (2004) Corporate governance and firm value: Evidence from the korean financial crisis. Journal of Financial economics 71(2):265-313

Berglöf E, Perotti E (1994) The governance structure of the japanese financial keiretsu. Journal of financial Economics 36(2):259-284

Bethel JE, Liebeskind J (1993) The effects of ownership structure on corporate restructuring. Strategic Management Journal 14(S1):15-31

Bühner R, Rasheed A, Rosenstein J (1997) Corporate restructuring patterns in the us and germany: a comparative empirical investigation. MIR: Management International Review pp 319-338

Cascio WF, Wynn P (2004) Managing a downsizing process. Human Resource Management 43(4):425-436

Charkham JP (1994) A larger role for institutional investors. Capital Markets and Corporate Governance, Oxford pp 99-110 
Colpan AM, Yoshikawa T, Hikino T, Miyoshi H (2007) Japanese corporate governance: Structural change and financial performance. Asian Business \& Management 6(1):S89-S113

David P, Yoshikawa T, Chari MD, Rasheed AA (2006) Strategic investments in japanese corporations: Do foreign portfolio owners foster underinvestment or appropriate investment? Strategic Management Journal 27(6):591-600

Dore RP (2000) Stock market capitalism: Welfare capitalism: Japan and Germany versus the Anglo-Saxons. Oxford University Press on Demand

Filatotchev I, Buck T, Zhukov V (2000) Downsizing in privatized firms in russia, ukraine, and belarus. Academy of Management Journal 43(3):286-304

Gillan S, Starks L (2003) Corporate governance, corporate ownership, and the role of institutional investors: A global perspective

Harris P, Lyon D, et al (2004) Montréal. Compass American Guides

Hirschman AO (1954) Economics and investment planning: reflections based on experience in colombia. Hirschman (1971) pp 41-62

Hodder JE, Tschoegl AE (1993) Corporate finance in Japan. 279, Center for Economic Policy Research, Stanford University

Hoskisson RE, Hitt MA (1990) Antecedents and performance outcomes of diversification: A review and critique of theoretical perspectives. Journal of management 16(2):461-509

Hoskisson RE, Turk TA (1990) Corporate restructuring: Governance and control limits of the internal capital market. Academy of Management Review 15(3):459-477

Hoskisson RE, Johnson RA, Moesel DD (1994) Corporate divestiture intensity in restructuring firms: Effects of governance, strategy, and performance. Academy of Management journal 37(5):1207-1251

Hoskisson RE, Johnson RA, Tihanyi L, White RE (2005) Diversified business groups and corporate refocusing in emerging economies. Journal of Management 31(6):941-965

Inoue H (1999) The accelerating dissolution of stock cross-holding. Tokyo: NLI Research Institute

Jensen MC (1986) Agency costs of free cash flow, corporate finance, and takeovers. The American economic review 76(2):323-329

Johnson S, Boone P, Breach A, Friedman E (2000) Corporate governance in the asian financial crisis. Journal of financial Economics 58(1-2):141-186

Kang JK, Shivdasani A (1997) Corporate restructuring during performance declines in japan. Journal of Financial Economics 46(1):29-65

Khanna T, Palepu K (2000) Is group affiliation profitable in emerging markets? an analysis of diversified indian business groups. The Journal of Finance 55(2):867-891

Kim H, Hoskisson RE, Wan WP (2004) Power dependence, diversification strategy, and performance in keiretsu member firms. Strategic Management Journal 25(7):613-636

La Porta R, Lopez-de Silanes F (1999) The benefits of privatization: Evidence from mexico. The Quarterly Journal of Economics 114(4):1193-1242

La Porta R, Lopez-de Silanes F, Shleifer A, Vishny RW (1997) Legal determinants of external finance. Journal of finance pp 1131-1150

La Porta R, Lopez-de Silanes F, Shleifer A, Vishny R (2000) Investor protection and corporate governance. Journal of financial economics $58(1): 3-27$

Lazonick W, O'sullivan M (2000) Maximizing shareholder value: a new ideology for corporate governance. Economy and society 29(1):13-35

Lehn K, Poulsen A (1989) Free cash flow and stockholder gains in going private transactions. The Journal of Finance 44(3):771-787

Lincoln JR, Gerlach ML (2004) Japan's network economy: Structure, persistence, and change, vol 24. Cambridge University Press

Lincoln JR, Gerlach ML, Ahmadjian CL (1996) Keiretsu networks and corporate performance in japan. American sociological review pp $67-88$

Makhija AK, Patton JM (2004) The impact of firm ownership structure on voluntary disclosure: Empirical evidence from czech annual reports. The Journal of Business 77(3):457-491

Megginson WL, Nash RC, Randenborgh M (1994) The financial and operating performance of newly privatized firms: An international empirical analysis. The Journal of Finance 49(2):403-452

Mitchell ML, Lehn K (1990) Do bad bidders become good targets? Journal of Political Economy $98(2): 372-398$

Business Review: (2017) 12(2):33-64 
Miwa Y, Ramseyer JM (2005) Who appoints them, what do they do? evidence on outside directors from japan. Journal of Economics \& Management Strategy 14(2):299-337

Murphy KM, Shleifer A, Vishny RW (1991) The allocation of talent: Implications for growth. The quarterly journal of economics 106(2):503-530

Parrino R, Sias RW, Starks LT (2003) Voting with their feet: Institutional ownership changes around forced ceo turnover. Journal of financial economics 68(1):3-46

Prowse SD (1992) The structure of corporate ownership in japan. The Journal of Finance 47(3):1121-1140

Rajan RG, Zingales L (1998) Power in a theory of the firm. The Quarterly Journal of Economics 113(2):387-432

Ryan LV, Schneider M (2002) The antecedents of institutional investor activism. Academy of Management Review 27(4):554-573

Shleifer A, Vishny RW (1991) Takeovers in the'60s and the'80s: Evidence and implications. Strategic management journal 12(S2):51-59

Wright M, Filatotchev I, Hoskisson RE, Peng MW (2005) Strategy research in emerging economies: Challenging the conventional wisdom. Journal of management studies 42(1):133

Xu X, Wang Y (1999) Ownership structure and corporate governance in chinese stock companies. China economic review 10(1):75-98 


\section{Appendix}

Table A1: Data set

\begin{tabular}{|c|c|c|}
\hline No & Name of Industrial Sector & No of companies \\
\hline 1 & Air transportation & 2 \\
\hline 2 & Chemicals & 73 \\
\hline 3 & Construction & 78 \\
\hline 4 & Electric appliances & 58 \\
\hline 5 & Electric power \& gas & 6 \\
\hline 6 & Fishery, agriculture \& forestry & 2 \\
\hline 7 & Foods & 44 \\
\hline 8 & Glass \& ceramics products & 20 \\
\hline 9 & Information \& communication & 73 \\
\hline 10 & Iron \& steel & 16 \\
\hline 11 & Land transportation & 8 \\
\hline 12 & Machinery & 86 \\
\hline 13 & Marine transportation & 3 \\
\hline 14 & Metal products & 34 \\
\hline 15 & Nonferrous metals & 9 \\
\hline 16 & Oil \& coal products & 4 \\
\hline 17 & Other financing business & 3 \\
\hline 18 & Other products & 35 \\
\hline 19 & Pharmaceutical & 21 \\
\hline 20 & Precision instruments & 10 \\
\hline 21 & Pulp \& paper & 6 \\
\hline 22 & Real estate & 22 \\
\hline 23 & Retail trade & 134 \\
\hline 24 & Rubber products & 5 \\
\hline 25 & Securities \& commodity futures & 3 \\
\hline 26 & Services & 94 \\
\hline 27 & Textile \& apparel & 16 \\
\hline 28 & Transport equipment & 37 \\
\hline 29 & Warehousing and harbor transportation & 15 \\
\hline \multirow[t]{2}{*}{30} & Wholesale trade & 99 \\
\hline & Total & 1016 \\
\hline
\end{tabular}

Business Review: (2017) 12(2):33-64 


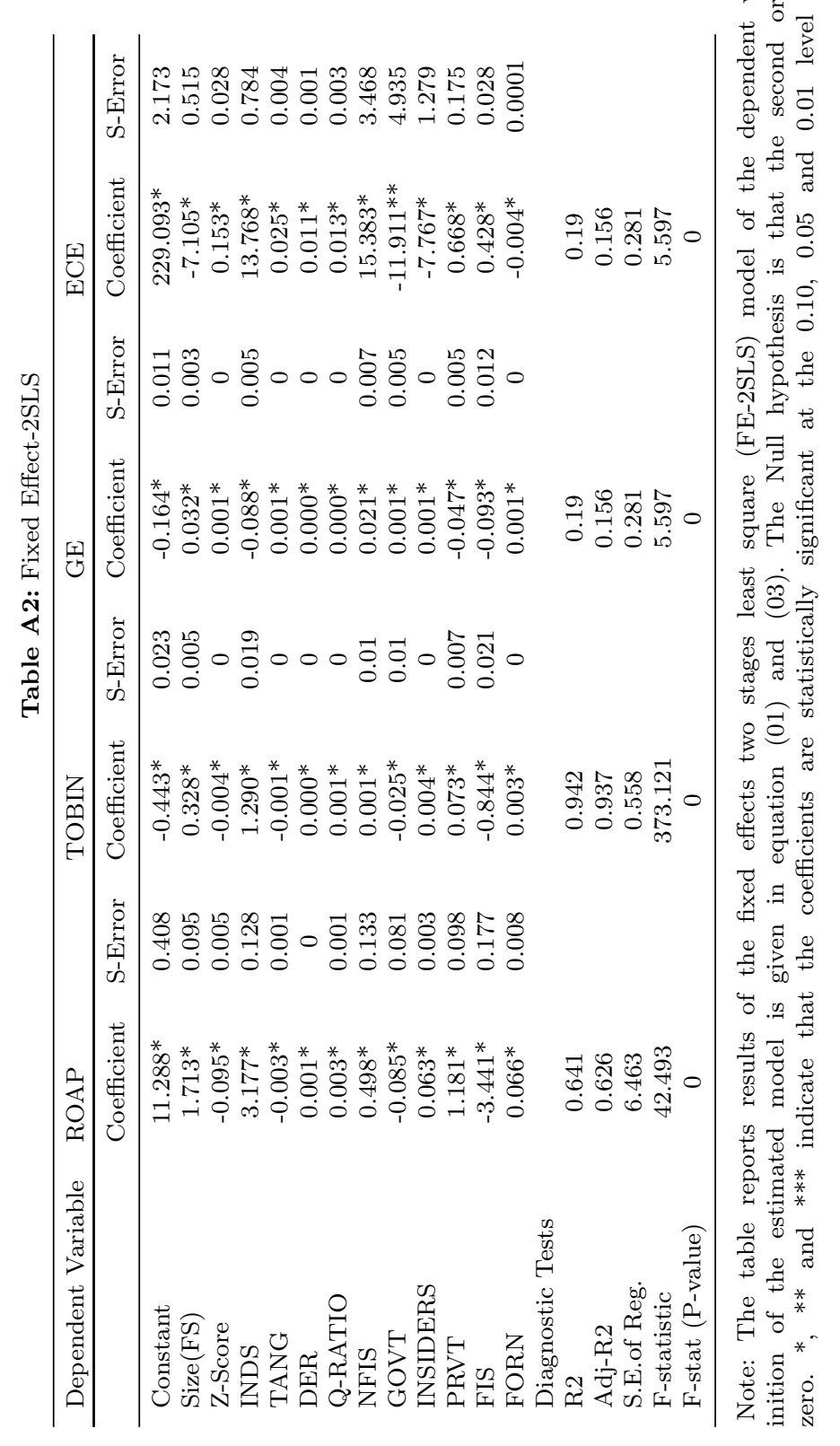

